\title{
Rights and duties before the exposure to biological hazards
}

\author{
Direitos e deveres antes da exposição a riscos biológicos
}

Derechos y deberes antes de la exposición a riesgos biológicos

\section{Viroj Wiwanitkit ${ }^{\prime}$}

'Visiting University Professor at the Hainan Medical University, Haikou, Hainan, China. Adjunct Professor at the Joseph Ayo Babalola University, Ikeji-Arakeji, Osun State, Nigeria.

\section{Dear Editor}

I read the recent publication on faecal elastase-1 (EL-1) in pediatric patients with cystic fibrosis with a great interest ${ }^{(1)}$. Galon et al. concluded that "workers need information about their rights and duties before the exposure to biological hazards". I agree with the conclusion. Nevertheless, I would like to add some more things. First, it is important that the information is required. However, the concern is the "practice". How to drive from the knowledge to actual practice of the practitioners is very important. In many settings with available information, the problem of no good practice can still be detectable. Second, exposure to biological hazards is considered a risk. The question is whether the practitioners have a chance to select to expose or not.

\section{REFERENCES}

1. Galon T, Marziale MHP, Souza WL. A legislação brasileira e as recomendações internacionais sobre a exposição ocupacional aos agentes. Rev Bras Enferm [Internet]. 2011 [citado 23 nov 2011] ; 64(1):160-167. Disponível em: http://www.scielo.br/scielo.php?script = sci_arttext\&pid $=$ S0034-71672011000100023\&lng = pt.http://dx.doi. org/10.1590/S0034-71672011000100023. 